\title{
Calcium-Dependent Desensitization of Vanilloid Receptor TRPV1: A Mechanism Possibly Involved in Analgesia Induced by Topical Application of Capsaicin
}

\section{VYKLICKÝ, K. NOVÁKOVÁ-TOUŠOVÁ, J. BENEDIKT, A. SAMAD, F. TOUŠKA, V. VLACHOVÁ}

Department of Cellular Neurophysiology, Institute of Physiology, Academy of Sciences of the Czech Republic, v.v.i, Prague, Czech Republic

Received February 15, 2008

Accepted April 16, 2008

On-line May 13, 2008

\section{Summary}

The rationale for the topical application of capsaicin and other vanilloids in the treatment of pain is that such compounds selectively excite and subsequently desensitize nociceptive neurons. This desensitization is triggered by the activation of vanilloid receptors (TRPV1), which leads to an elevation in intracellular free $\mathrm{Ca}^{2+}$ levels. Depending on the vanilloid concentration and duration of exposure, the $\mathrm{Ca}^{2+}$ influx via TRPV1 desensitizes the channels themselves, which may represent not only a feedback mechanism protecting the cell from toxic $\mathrm{Ca}^{2+}$ overload, but also likely contributes to the analgesic effects of capsaicin. This review summarizes the current state of knowledge concerning the mechanisms that underlie the acute capsaicin-induced $\mathrm{Ca}^{2+}$-dependent desensitization of TRPV1 channels and explores to what extent they may contribute to capsaicin-induced analgesia. In view of the polymodal nature of TRPV1, we illustrate how the channels behave in their desensitized state when activated by other stimuli such as noxious heat or depolarizing voltages. We also show that the desensitized channel can be strongly reactivated by capsaicin at concentrations higher than those previously used to desensitize it. We provide a possible explanation for a high incidence of adverse effects of topical capsaicin and point to a need for more accurate clinical criteria for employing it as a reliable remedy.

\section{Key words}

TRPV1 receptors - Capsaicin - Topical application • Desensitization • Analgesia

\section{Corresponding author}

V. Vlachová, Institute of Physiology AS CR, Vídeňská 1083, 142 20 Prague 4, Czech Republic, Fax. 420-29644-2488, E-mail: vlachova@biomed.cas.cz

\section{Introduction}

Capsaicin produces burning pain in humans when brought into contact with the corium or mucosa and, paradoxically, its topical application to the skin has been found useful in the treatment of some pain states in traditional and contemporary medicine (for reviews, see Szallasi and Blumberg 1999, Sawynok 2003, Nagy et al. 2004). Experimental evidence has been presented that capsaicin causes persistent functional desensitization of polymodal primary nociceptors after repeated or prolonged application (Jancso et al. 1967, Carpenter and Lynn 1981, Szolcsanyi 2004). This desensitization was suggested to occur rather due to physiological than to morphological alterations (McMahon et al. 1991), however, later convincing evidence was presented that repeated capsaicin application to the skin produces a degeneration of epidermal nerve fibers that may underlie this type of analgesia (Simone et al. 1998, Nolano et al. 1999). Although capsaicin and other vanilloids have been shown to disrupt some vital organelles and promote apoptosis in various cell types (Hail 2003 and references therein), most of the well characterized effects are mediated through the activation of a specific receptor-ion channel that is natively 

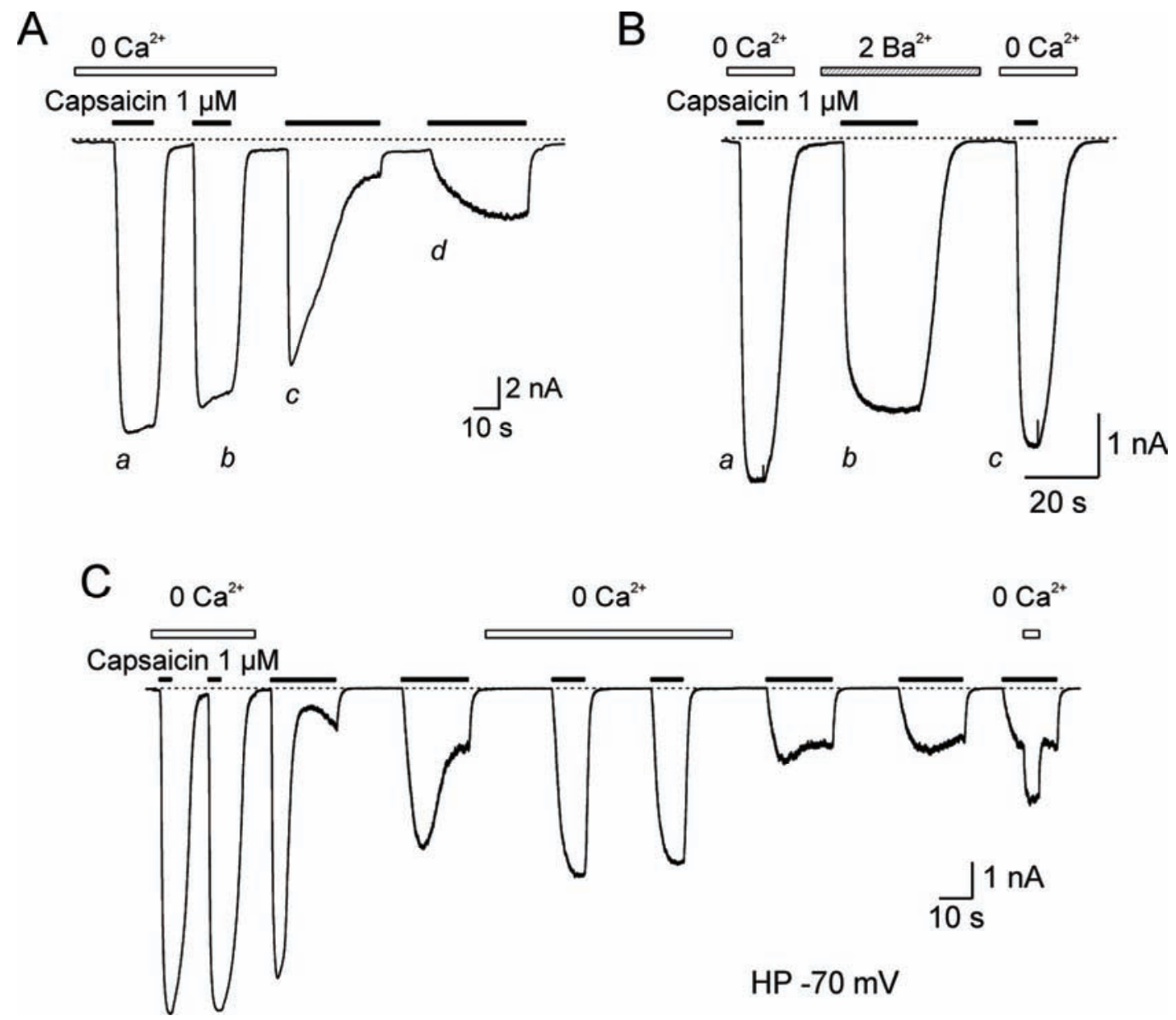

Fig. 1. Effects of extracellular $\mathrm{Ca}^{2+}$ on acute desensitization of capsaicin-activated currents in HEK293T cells transfected with rat TRPV1. (A) Whole-cell current responses to consecutive applications of $1 \mu \mathrm{M}$ capsaicin induced in a nominally $\mathrm{Ca}^{2+}$-free extracellular solution (a and $b$ ) and in standard bath solution containing $1 \mathrm{mM} \mathrm{Ca}^{2+}(c$ and $d)$. The methods used in this study are described in detail in Novakova-Tousova et al. (2007). Briefly, human embryonic kidney (HEK) 293T cells, transiently transfected with recombinant plasmid CDNA encoding wild-type rat TRPV1, were used for whole-cell recordings using a conventional patch-clamp technique. The cells were superfused with an extracellular control solution (ECS) (mM): $\mathrm{NaCl}, 160 ; \mathrm{KCl}, 2.5 ; \mathrm{CaCl}_{2}, 1 ; \mathrm{MgCl}_{2}, 2 ; \mathrm{HEPES}, 10 ;$ glucose 10 . The intracellular pipette solution contained (mM): Cs-gluconate, 125; CsCl, 15; EGTA, 5; HEPES, 10; $\mathrm{CaCl}_{2}, 0.5 ;$ MgATP, 2; pH was adjusted to 7.3 with $\mathrm{CsOH}$. Holding potential was $-70 \mathrm{mV}$. Capsaicin was applied for the durations indicated by the bars above the records. Dashed lines indicate zero current level. (B) Barium cannot substitute for $\mathrm{Ca}^{2+}$ in acute capsaicin-induced desensitization of the TRPV1 channel. Capsaicin $(1 \mu \mathrm{M})$ was applied either in $\mathrm{Ca}^{2+}$-free solution to which $1 \mathrm{mM}$ EGTA was added $(a, c)$ or in the bath solution in which $\mathrm{Ba}^{2+}(2 \mathrm{mM})$ was substituted for $\mathrm{Ca}^{2+}(b)$. (C) Whole-cell membrane currents from another TRPV1-HEK293T cell. Capsaicin was applied in $\mathrm{Ca}^{2+}$-free solution to which $1 \mathrm{mM}$ EGTA was added to chelate residual $\mathrm{Ca}^{2+}\left(0 \mathrm{Ca}^{2+}\right)$ or in solution containing $2 \mathrm{mM} \mathrm{Ca}^{2+}$.

expressed in mammalian primary nociceptors (Caterina et al. 1997). This receptor was termed vanilloid receptor subtype 1 (TRPV1) because it became the founding member of the vanilloid receptor subfamily of transient receptor potential (TRP) channels, a large superfamily of nonselective cation channels that play an important role in many sensory functions (for recent reviews see Clapham 2003, Planells-Cases et al. 2005, Tominaga and Tominaga 2005, Bandell et al. 2007, Nilius et al. 2007, Pingle et al. 2007, Venkatachalam and Montell 2007). Although the molecular identification of the TRPV1 channels has greatly facilitated understanding the mechanisms by which vanilloids increase and subsequently attenuate nociceptor activity, there is still no general consensus about the in vivo role of these mechanisms in the development of vanilloidinduced analgesia. What is clear from research carried out to date is that this process is triggered by $\mathrm{Ca}^{2+}$ influx via TRPV1, which leads to desensitization of the channel protein complex itself and, in extreme cases, to the degeneration of TRPV1-expressing sensory neurons due to $\mathrm{Ca}^{2+}$ overload (Olah et al. 2001, Szolcsanyi 2004, Tender et al. 2005).

In vitro studies on native and recombinant channels demonstrate that TRPV1 exhibits two types of desensitization, both of which frequently occur in conjunction (Figs 1A and 1C): acute desensitization, which is a diminished response during a continuous vanilloid application, and tachyphylaxis, which is a 
reduction in the response to repeated applications (Docherty et al. 1996, Koplas et al. 1997, Bhave et al. 2003). Over the past decade, it has become apparent that a predominant fast (acute) component of TRPV1 desensitization, in both native and overexpression contexts, critically depends on $\mathrm{Ca}^{2+}$ influx through the channel (Koplas et al. 1997, Piper et al. 1999, Mohapatra and Nau 2003, Numazaki et al. 2003, Rosenbaum et al. 2004, Lishko et al. 2007). Although it is not yet certain whether the acute desensitization and tachyphylaxis share the same cellular mechanisms (Docherty et al. 1996, Koplas et al. 1997), there is good evidence that it is the acute phase that accounts for most of the diminution of responsiveness occurring within the first few seconds after vanilloids are applied for the first time to a cell (Cholewinski et al. 1993, Liu and Simon 1996).

In this review, we present an update on findings concerning the mechanisms that underlie acute capsaicininduced $\mathrm{Ca}^{2+}$-dependent desensitization of the TRPV1 channel and argue that further study is needed to clarify the contribution of these mechanisms to capsaicininduced analgesia.

\section{No single molecular mechanism alone (such as the dephosphorylation of TRPV1) can account for the whole phenotype of capsaicin-induced $\mathrm{Ca}^{2+}$-dependent desensiti- zation}

Among the $\mathrm{Ca}^{2+}$-activated enzymes that were reported to modulate TRPV1 desensitization is the $\mathrm{Ca}^{2+} /$ calmodulin-dependent serine/threonine phosphatase 2B, calcineurin, which dephosphorylates TRPV1 receptors (Docherty et al. 1996, Mohapatra and Nau 2005). Conversely, phosphorylations at several consensus sites for protein kinase $\mathrm{C}$ (PKC), cAMP-dependent protein kinase $\mathrm{A}$ (PKA) and $\mathrm{Ca}^{2+} /$ calmodulin dependent kinase II (CaMKII) have been shown to reduce the $\mathrm{Ca}^{2+}$ mediated desensitization of TRPV1. There are a number of putative phosphorylation sites at which the TRPV1 channel can be regulated: S502 and S800 have been implicated as targets of PKC-dependent phosphorylation (Vellani et al. 2001, Numazaki et al. 2002, Bhave et al. 2003, Mandadi et al. 2004, Mandadi et al. 2006) and S116, T144, T370, and S502 were identified as the key sites at which PKA phosphorylation increases the open probability and reverses desensitization of the channel (Bhave et al. 2002, Mohapatra and Nau 2003, Mohapatra and Nau 2005). A coincident phosphorylation of S502 and T704 by CaMKII has been proposed to be a necessary condition for the vanilloid binding capacity of TRPV1 (Jung et al. 2004). From these findings it was inferred that it is mostly a functional reflection of the dynamic balance between the $\mathrm{Ca}^{2+}$-dependent phosphorylation and dephosphorylation of the receptor protein that accounts for the desensitization of the TRPV1 channel. Later, evidence was presented that the TRPV1 desensitization might involve a much more complex $\mathrm{Ca}^{2+}$-dependent pathways. Acute $\mathrm{Ca}^{2+}$ dependent TRPV1 desensitization has been shown to be accompanied by a profound change in voltage dependence (Piper et al. 1999, Gunthorpe et al. 2000), loss of capsaicin binding (Jung et al. 2004), and depletion of membrane phosphatidylinositol 4,5-bisphosphate $\left(\mathrm{PIP}_{2}\right)$, indicative of the involvement of $\mathrm{Ca}^{2+}$-dependent PLC activity in this process. A role for ATP was also suggested, based on the evidence that the recovery from desensitization requires a high cytoplasmic concentration of ATP to replenish PIP $_{2}$ (Liu et al. 2005). Mutation of the aromatic tyrosine residue Y671 within the internal pore of the TRPV1 channel greatly reduced $\mathrm{Ca}^{2+}$ dependent desensitization, suggesting that this residue is also involved in the structural rearrangements of the channel protein complex (Mohapatra et al. 2003). Although in many cases it could not be clearly distinguished which of these processes are primarily direct causes of desensitization rather than consequences of TRPV1 activation, it became clear that the dephosphorylation of TRPV1 represents only one of the possible mechanisms involved in analgesia after the topical application of capsaicin.

\section{The prevention of acute desensitization of the TRPV1 channel by substituting $\mathrm{Ba}^{2+}$ for $\mathrm{Ca}^{2+}$ highlights a possible role for calmodulin}

Structurally, like other members of the TRP channel superfamily, TRPV1 channels are homotetramers assembled around a centrally located aqueous pore (for a review, see Owsianik et al. 2006). Each subunit contains six transmembrane spanning domains (S1-S6) with a pore-lining $\mathrm{P}$ region linking the $\mathrm{S} 5$ and $\mathrm{S} 6$ domains. Although the crystal structure of the transmembrane part is not yet available for any of the TRP channels, it is generally accepted that it is analogous to the molecular architecture of the voltage-gated potassium channels: S1S4 are putatively located on or close to the protein-lipid interface, whereas the four S5-P-S6 segments form the 

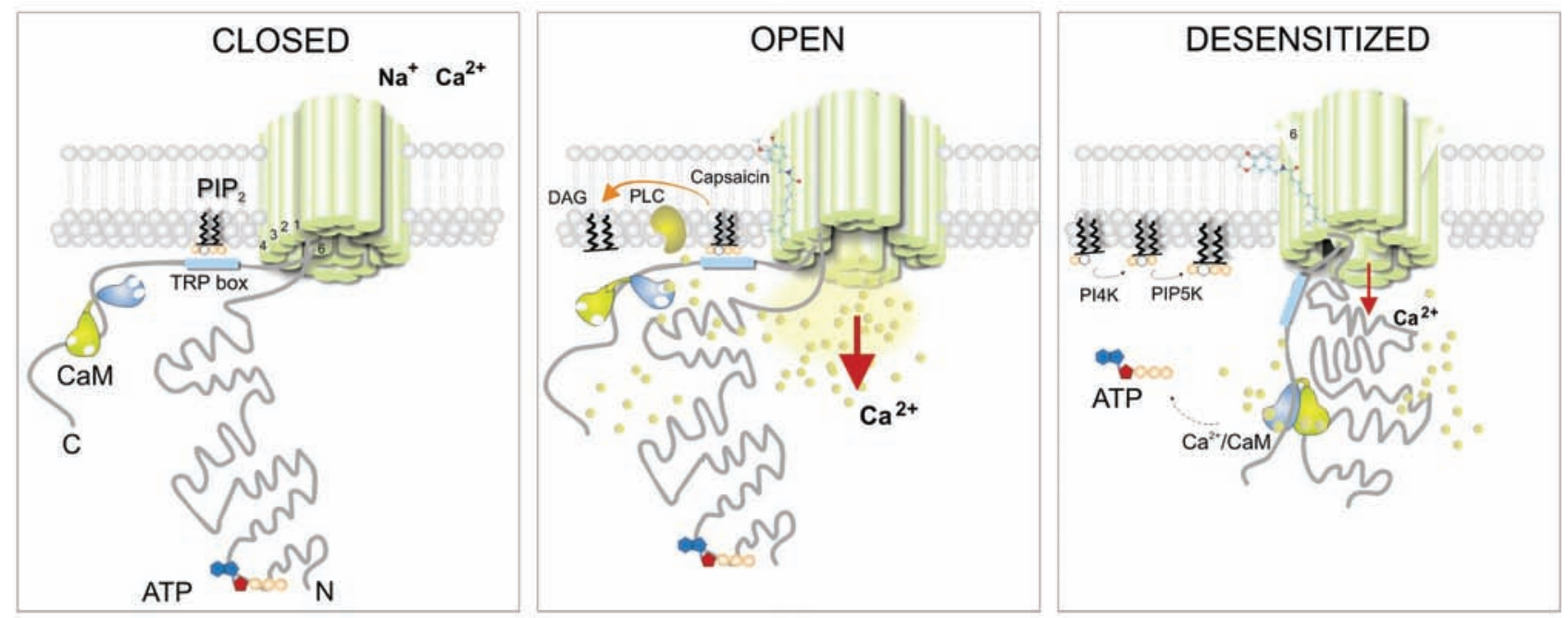

Fig. 2. Tentative model of TRPV1 capsaicin-induced $\mathrm{Ca}^{2+}$-dependent desensitization. The cytosolic ankyrin-repeat domain of TRPV1 (residues 101-364) binds ATP and calmodulin in a $\mathrm{Ca}^{2+}$-dependent manner competes with ATP at the same interaction site (Lishko et al. 2007). These two competitors have opposite effects on TRPV1 channel activity: ATP sensitizes the channel whereas the Ca ${ }^{2+}$-CaM complex inhibits it. A short C-terminal juxtamembrane segment adjacent to the TRP box (most likely around R701) is predicted to contribute to the interaction with membrane phosphatidylinositol 4,5-bisphosphate $\left(\mathrm{PIP}_{2}\right)$ and might be involved in the slowed gating kinetics of the desensitized TRPV1 channel. The capsaicin molecule binds to the TRPV1 receptor at the channel-lipid interface between S3 and S4. $\mathrm{Ca}^{2+}$-dependent activation of phospholipase $\mathrm{C}(\mathrm{PLC})$ results in the hydrolysis of localized $\mathrm{PIP}_{2}$ to $1,4,5$-trisphosphate and diacylglycerol (DAG), leading to inactivation of the TRPV1 channel. Acute desensitization could alter the $\mathrm{Ca}^{2+}$-dependent allosteric coupling between the capsaicin binding site and the PIP ${ }_{2}$-sensitive gating apparatus of the TRPV1 channel. A high concentration of intracellular ATP is required for $\mathrm{PIP}_{2}$ resynthesis by sequential phosphorylation of its precursor phosphatidylinositol by phosphatidylinositol 4-kinases (PI4K) and phosphatidylinositol 4-phosphate 5-kinases (PIP5K).

pore. Upon activation, $\mathrm{Ca}^{2+}$ permeates the TRPV1 channel pore more readily than other external cations $\left(\mathrm{P}_{\mathrm{Ca}} / \mathrm{P}_{\mathrm{Na}} \sim 10, \mathrm{P}_{\mathrm{Mg}} / \mathrm{P}_{\mathrm{Na}} \sim 5\right)$. So, at negative membrane potentials, the driving force is favorable for a strong $\mathrm{Ca}^{2+}$ influx. If $\mathrm{Ba}^{2+}$ is used as the charge carrier instead of $\mathrm{Ca}^{2+}$ in whole-cell patch-clamp experiments on cells that express TRPV1 channels, capsaicin induces responses that do not desensitize and only slightly decrease in magnitude when compared to the responses induced by capsaicin in $\mathrm{Ca}^{2+}$-free extracellular solution (Fig. 1B). Although consistent effects are observed in heterologous expression systems (Gunthorpe et al. 2000, McNamara et al. 2005), earlier studies found that $\mathrm{Ba}^{2+}$ supports acute desensitization and tachyphylaxis of capsaicin-induced responses in native TRPV1 channels in DRG neurons isolated from rats, a result which has been interpreted by Koplas et al. (1997) as showing that $\mathrm{Ba}^{2+}$ can activate calcineurin-dependent dephosphorylation independently of calmodulin. This important calcium downstream effector was proposed to mediate TRPV1 desensitization more than a decade ago (Docherty et al. 1996) and this role has been debated ever since. $\mathrm{Ba}^{2+}$ as a surrogate for $\mathrm{Ca}^{2+}$ substitutes poorly at $\mathrm{Ca}^{2+}$-sensitive regulatory sites and is also a poor substrate for $\mathrm{Ca}^{2+}$ transport mechanisms. Apparently because of its larger effective ionic radius than $\mathrm{Ca}^{2+}(1.38 \AA$ versus $1.06 \AA), \mathrm{Ba}^{2+}$ also does not bind to calmodulin (CaM) (Chao et al. 1984). More recently, the TRPV1 channel has been shown to directly bind $\mathrm{CaM}$ at two sites in both a $\mathrm{Ca}^{2+}$-dependent and $\mathrm{Ca}^{2+}$-independent manner. One of these sites was localized in the N-terminal region (Rosenbaum and Gordon 2002, Lishko et al. 2007) whereas the other has been identified in the C-terminal domain (Numazaki et al. 2003). One of the most comprehensive models for the $\mathrm{Ca}^{2+}$-induced desensitization of the TRPV1 channel has emerged from these studies (Fig. 2). The picture is built largely on recent evidence suggesting that the cytosolic ankyrin-repeat domain of TRPV1 (residues 101-364) binds ATP and that calmodulin, in a $\mathrm{Ca}^{2+}$-dependent manner, competes with ATP at the same interaction site (Lishko et al. 2007). These two competitors have opposite effects on TRPV1 channel activity: ATP sensitizes the channel whereas $\mathrm{Ca}^{2+}{ }_{-} \mathrm{CaM}$ inhibits it.

\section{The apparent affinity for capsaicin is decreased in a desensitized TRPV1 channel}

Acute TRPV1 desensitization depends not only on the amount of calcium influx, but also on the type of agonist. Camphor, a waxy substance used topically for its analgesic and counterirritant properties, activates TRPV1 independently of the vanilloid binding site and 
A

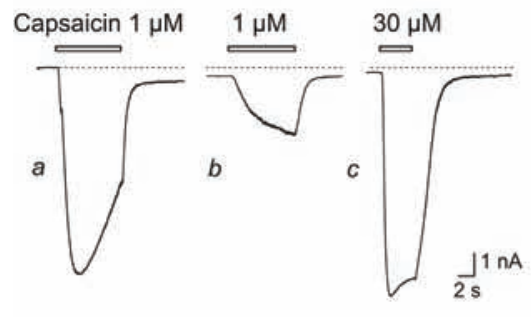

B

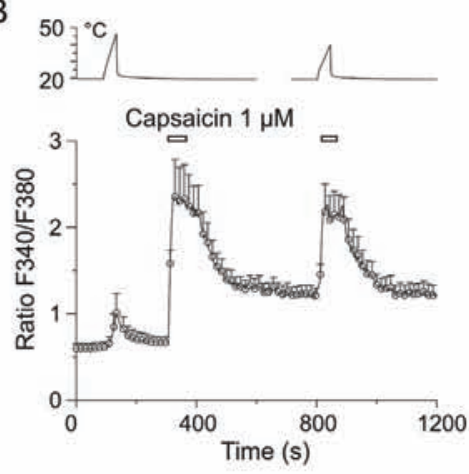

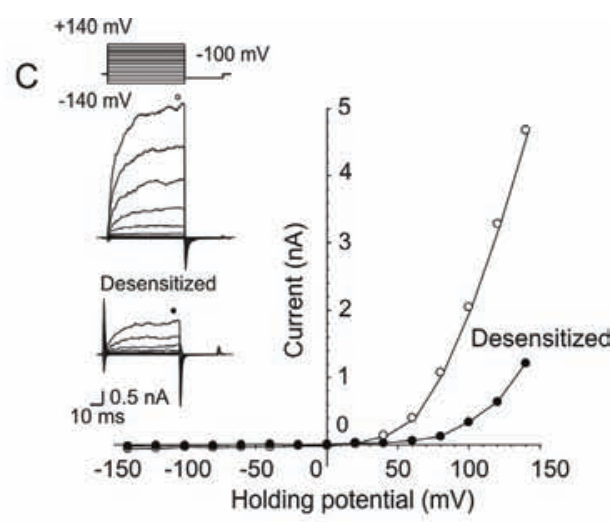

$E$

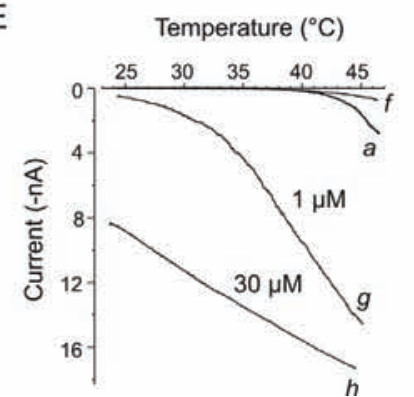

Fig. 3. (A) Capsaicin applied at high concentration $(30 \mu \mathrm{M})$ reactivates TRPV1 channels that had previously been desensitized to $1 \mu \mathrm{M}$ capsaicin in $\mathrm{Ca}^{2+}$-containing bath solution $(2 \mathrm{mM})$. (B) Changes in intracellular calcium concentration induced by consequent applications of a heat ramp $\left(20-48{ }^{\circ} \mathrm{C}\right.$ in $\left.30 \mathrm{~s}\right), 1 \mu \mathrm{M}$ capsaicin and a temperature ramp $\left(20-42^{\circ} \mathrm{C}\right)$ applied in the presence of capsaicin, monitored using ratiometric $\mathrm{Ca}^{2+}$-imaging in the presence of $2 \mathrm{mM} \mathrm{Ca}^{2+}\left(n=6\right.$ cells). For microfluorometric Ca ${ }^{2+}$ measurements, TRPV1-expressing HEK293T cells were incubated in extracellular solution containing $2 \mu$ M FURA-2 AM for 45 min at $37^{\circ} \mathrm{C}$. (C, D, E) The effects of acute $\mathrm{Ca}^{2+}$-dependent capsaicin-induced desensitization on the gating of TRPV1 by other modalities. (C) Time course of TRPV1-mediated whole-cell currents induced by depolarizing voltage steps recorded at $25^{\circ} \mathrm{C}$ in extracellular control solution (holding potential $-70 \mathrm{mV}$, voltage steps from -140 to $+140 \mathrm{mV}$, increment $+20 \mathrm{mV}$ ) before (open circles) and after (filled circles) desensitization evoked by $1 \mu \mathrm{M}$ capsaicin. Current-voltage relationship for currents obtained before and after acute desensitization such as shown in the inset. (D) Whole-cell current responses to consecutive applications of a heat ramp (from $25^{\circ} \mathrm{C}$ to $48{ }^{\circ} \mathrm{C}$ in $3 \mathrm{~s}$ ) (a) and capsaicin $(1 \mu \mathrm{M}$ and $30 \mu \mathrm{M})(b-e)$ in a $\mathrm{Ca}^{2+}$-containing bath solution. Consecutive currents recorded in response to heat ramps applied in a standard bath solution $(f)$, in the presence of $1 \mu \mathrm{M}(g)$ and $30 \mu \mathrm{M}(h)$ capsaicin. Current-temperature relationships for currents shown in $(a, f h)$ demonstrate a strong potentiating effect of capsaicin on the heat-induced currents.

desensitizes it in a $\mathrm{Ca}^{2+}$-independent manner (Xu et al. 2005). Another natural product, piperine, the pungent component of black pepper, has a higher degree of cooperativity (Hill coefficient $\sim 4$ ) and a clear propensity to cause greater desensitization of TRPV1 than capsaicin (McNamara et al. 2005), even in the absence of $\mathrm{Ca}^{2+}$ in the bath. It therefore appears that structural rearrangements in the TRPV1 channel complex include not only the putative phosphorylation sites but also several domains in or near the agonist-binding site or sites that undergo conformational changes inactivating the channel. In contrast to the rapid onset of the first capsaicin response recorded in a $2 \mathrm{mM} \mathrm{Ca}^{2+}$-containing bath solution, the time constant characterizing the activation of the subsequent response is slower by about one order of magnitude (Fig. 1A). This might be the result of a decreased apparent affinity of desensitized TRPV1 receptors for capsaicin, which is also supported by the observation that $\left[{ }^{3} \mathrm{H}\right] \mathrm{RTX}$ does not bind to desensitized TRPV1 (Jung et al. 2004). Indeed, in the presence of $2 \mathrm{mM} \mathrm{Ca}^{2+}$, desensitization of the recombinant TRPV1 receptor after exposure to $1 \mu \mathrm{M}$ capsaicin can be overcome when its concentration is increased to $30 \mu \mathrm{M}$ (Fig. 3A).

A mutant TRPV1 channel S502A/T704I in which two putative consensus sites for CaMKII are simultaneously (but not individually) replaced with nonphosphorylatable residues is insensitive to capsaicin (Jung et al. 2004). However, another nonphosphorylatable mutant $\mathrm{S} 502 \mathrm{~A} / \mathrm{T} 704 \mathrm{~A}$ is fully functional, indicating the requirement for a specific residue at position 704 (Novakova-Tousova et al. 2007). Moreover, a point mutation at arginine residue R701 that, together with $\mathrm{T} 704$, lies within a short C-terminal juxtamembrane segment adjacent to the TRP box, strongly affected the kinetics of capsaicin-evoked currents. As this residue 
constitutes a stringent CaMKII consensus site but is also predicted to contribute to the interaction with membrane $\mathrm{PIP}_{2}$, it has been proposed that it might be involved in the slowed gating kinetics of the desensitized TRPV1 channel. The capsaicin molecule binds to the TRPV1 receptor at the channel-lipid interface between S3 and S4 and interacts with the residues around tyrosine 511, not far from the ,universal“ phosphorylation site S502, positioned at the cytoplasmic loop linking S2 and S3. Based on these findings, it seems that the domains around S502 and T704 are functionally linked and might also be located relatively close to one another, jointly influencing the binding of capsaicin. T704 is critical to the activation of TRPV1 by phorbol esters (Bhave et al. 2003), which indicates that it might act as an allosteric site.

\section{Functional changes in the vanilloid receptor subtype 1 channel (TRPV1) after acute desensitization}

The TRPV1 channel can be activated not only by vanilloid compounds but also by protons $(\mathrm{pH}<6.5)$, noxious heat $\left(>43{ }^{\circ} \mathrm{C}\right.$ ), phorbol esters (Premkumar and Ahern 2000, Bhave et al. 2003) or depolarizing voltages (Vlachová et al. 2003, Voets et al. 2004) (for recent reviews see Planells-Cases et al., 2005; Tominaga and Tominaga, 2005; Szallasi et al., 2006; Pingle et al., 2007). These stimuli, when applied alone, produce only submaximal activation, whereas the maximal response can only be reached by their synergistic interaction at the TRPV1 receptor channel complex (Tominaga et al. 1998). Such a polymodal activation property of TRPV1 certainly complicates the interpretation of functional data, since all stimuli lowering the activation energy for channel opening also lower the thermal threshold for activation and thus may seem to act as agonists at room temperature. Therefore, in comparison to the wealth of non-TRP ion channels that are gated by either ligands or membrane voltage, the activation of TRPV1 is an extremely complex and dynamic process involving multiple, allosterically coupled and stimulus-dependent pathways.

Although the desensitization of polymodal nociceptors by the local application of capsaicin can be considered specific, the complexity of the range of known pathways that lead from TRPV1 activation to increases in intracellular $\mathrm{Ca}^{2+}$ concentration and channel desensitization is dazzling and they involve almost every known type of signaling molecule (Planells-Cases et al.
2005, Tominaga and Tominaga 2005, Lukacs et al. 2007, Pingle et al. 2007). TRPV1 is not only expressed at the plasma membane but also resides in the endoplasmic reticulum where it forms channels that, upon binding the capsaicin that passes through the membrane, releases $\mathrm{Ca}^{2+}$ from internal stores (Liu et al. 2003, Marshall et al. 2003, Turner et al. 2003, Wisnoskey et al. 2003, Karai et al. 2004). This mechanism of activation may play an important role in $\mathrm{Ca}^{2+}$ signaling events localized to subcellular microdomains and may provide clues to the function of TRPV1 that we currently do not understand.

Calcium imaging experiments in cells transfected with the TRPV1 channel demonstrate that noxious heat $\left(>43^{\circ} \mathrm{C}\right)$ induces rapid and reversible cytosolic calcium transients. In contrast, the capsaicinevoked increase in intracellular $\mathrm{Ca}^{2+}$ concentration decays slowly and is maintained over a period of minutes (Fig. 3B). An increase in temperature from 25 to $40^{\circ} \mathrm{C}$ together with the application of capsaicin, a strong sensitizing stimulus for TRPV1, does not lead to enhanced $\mathrm{Ca}^{2+}$ influx when compared to the first capsaicin response. This seems to be in contrast to the synergy between heat and capsaicin observed under patch-clamp conditions (Fig. 3Dg). Although these experimental results have to be interpreted cautiously, for at least the above reasons, the $\mathrm{Ca}^{2+}$ accumulation clearly corresponds to the period of desensitization of the membrane current responses observed in cells clamped at a negative membrane potential $(-70 \mathrm{mV})$.

We and others have shown that various activators can cross-desensitize the TRPV1 channel (Tominaga et al. 1998, Vlachová et al. 2001). The capsaicin-induced $\mathrm{Ca}^{2+}$-dependent desensitization of the TRPV1 channel is accompanied by a decreased responsiveness to voltage and heat (Fig. 3C,D). In this case, the maximum amplitudes induced by simultaneous applications of heat together with capsaicin are even greater than the first maximal response to capsaicin obtained at room temperature (Fig. 3D $b$ and $g$ ), indicating that the activation capacity of desensitized channels is not significantly reduced. This consistent finding of the strong synergy between capsaicin and heat might provide a possible explanation for the adverse reactions observed in around one third of patients suffering from musculocutaneous or neuropathic pain, in which the local administration of capsaicin results in adverse events or even in an increase of pain above tolerable levels (Mason et al. 2004). 


\section{Conclusions}

Both the published data and our own results on the recombinant TRPV1 receptor suggest that multiple mechanisms are involved in the analgesia induced by topical application of capsaicin. We are still in the process of understanding them better in order to increase our ability to treat pain in cases when other means are unsatisfactory or potentially hazardous. Although the topical application of capsaicin remains a promising alternative for the treatment of patients who suffer from local pain that cannot be adequately treated by routine analgesics, the mechanisms involved in the reduction of the pain will need to be investigated further. Better characterization of the pain states suitable for such a treatment will also need to be an area of study to avoid adverse reactions and ensure a reliable remedy. The next challenge will be to understand the role of the TRPV1 channel in the process of nociceptor desensitization that occurs during topical capsaicin application and exploit this information for therapeutic ends in chronic neuropathic pain states such as diabetic neuropathy, postherpetic neuralgia, arthritis, musculoskeletal pain or inflammatory bowel disease. A clear understanding of the pathogenesis at the molecular and cellular levels of nociceptor function will be a significant step towards the development of more effective, better targeted and more specific pain therapies in the future.

\section{Conflict of Interest}

There is no conflict of interest.

\section{Acknowledgements}

This work was supported by the Czech Science Foundation, 305/06/0319, the Research Project Fund of the AS CR, AV0Z 5011922 and by the Ministry of Education, Youth and Sports of the Czech Republic, $1 \mathrm{M} 0517$ and LC 554.

\section{References}

BANDELL M, MACPHERSON LJ, PATAPOUTIAN A: From chills to chilis: mechanisms for thermosensation and chemesthesis via thermoTRPs. Curr Opin Neurobiol 17: 490-497, 2007.

BHAVE G, HU HJ, GLAUNER KS, ZHU W, WANG H, BRASIER DJ, OXFORD GS, GEREAU RWT: Protein kinase $\mathrm{C}$ phosphorylation sensitizes but does not activate the capsaicin receptor transient receptor potential vanilloid 1 (TRPV1). Proc Natl Acad Sci US A 100: 12480-12485, 2003.

BHAVE G, ZHU W, WANG H, BRASIER DJ, OXFORD GS, GEREAU RWT: cAMP-dependent protein kinase regulates desensitization of the capsaicin receptor (VR1) by direct phosphorylation. Neuron 35: 721-731, 2002.

CARPENTER SE, LYNN B: Vascular and sensory responses of human skin to mild injury after topical treatment with capsaicin. Br J Pharmacol 73: 755-758, 1981.

CATERINA MJ, SCHUMACHER MA, TOMINAGA M, ROSEN TA, LEVINE JD, JULIUS D: The capsaicin receptor: a heat-activated ion channel in the pain pathway. Nature 389: 816-824, 1997.

CHAO SH, SUZUKI Y, ZYSK JR, CHEUNG WY: Activation of calmodulin by various metal cations as a function of ionic radius. Mol Pharmacol 26: 75-82, 1984.

CHOLEWINSKI A, BURGESS GM, BEVAN S: The role of calcium in capsaicin-induced desensitization in rat cultured dorsal root ganglion neurons. Neuroscience 55: 1015-1023, 1993.

CLAPHAM DE: TRP channels as cellular sensors. Nature 426: 517-524, 2003.

DOCHERTY RJ, YEATS JC, BEVAN S, BODDEKE HW: Inhibition of calcineurin inhibits the desensitization of capsaicin- evoked currents in cultured dorsal root ganglion neurones from adult rats. Pflugers Arch 431: 828$837,1996$.

GUNTHORPE MJ, HARRIES MH, PRINJHA RK, DAVIS JB, RANDALL A: Voltage- and time-dependent properties of the recombinant rat vanilloid receptor (rVR1). J PhysiolLond 525: 747-759, 2000.

HAIL N, JR.: Mechanisms of vanilloid-induced apoptosis. Apoptosis 8: 251-262, 2003.

JANCSO N, JANCSO-GABOR A, SZOLCSANYI J: Direct evidence for neurogenic inflammation and its prevention by denervation and by pretreatment with capsaicin. Br J Pharmacol Chemother 31: 138-151, 1967.

JUNG J, SHIN JS, LEE SY, HWANG SW, KOO J, CHO H, OH U: Phosphorylation of vanilloid receptor 1 by $\mathrm{Ca}^{2+} /$ calmodulin-dependent kinase II regulates its vanilloid binding. J Biol Chem 279: 7048-7054, 2004. 
KARAI LJ, RUSSELL JT, IADAROLA MJ, OLAH Z: Vanilloid receptor 1 regulates multiple calcium compartments and contributes to $\mathrm{Ca}^{2+}$-induced $\mathrm{Ca}^{2+}$ release in sensory neurons. $J$ Biol Chem 279: 16377-16387, 2004.

KOPLAS PA, ROSENBERG RL, OXFORD GS: The role of calcium in the desensitization of capsaicin responses in rat dorsal root ganglion neurons. J Neurosci 17: 3525-3537, 1997.

LISHKO PV, PROCKO E, JIN X, PHELPS CB, GAUDET R: The ankyrin repeats of TRPV1 bind multiple ligands and modulate channel sensitivity. Neuron 54: 905-918, 2007.

LIU B, ZHANG C, QIN F: Functional recovery from desensitization of vanilloid receptor TRPV1 requires resynthesis of phosphatidylinositol 4,5-bisphosphate. J Neurosci 25: 4835-4843, 2005.

LIU L, SIMON SA: Capsaicin-induced currents with distinct desensitization and $\mathrm{Ca}^{2+}$ dependence in rat trigeminal ganglion cells. J Neurophysiol 75: 1503-1514, 1996.

LIU M, LIU MC, MAGOULAS C, PRIESTLEY JV, WILLMOTT NJ: Versatile regulation of cytosolic $\mathrm{Ca}^{2+}$ by vanilloid receptor I in rat dorsal root ganglion neurons. J Biol Chem 278: 5462-5472, 2003.

LUKACS V, THYAGARAJAN B, VARNAI P, BALLA A, BALLA T, ROHACS T: Dual regulation of TRPV1 by phosphoinositides. J Neurosci 27: 7070-7080, 2007.

MANDADI S, NUMAZAKI M, TOMINAGA M, BHAT MB, ARMATI PJ, ROUFOGALIS BD: Activation of protein kinase $\mathrm{C}$ reverses capsaicin-induced calcium-dependent desensitization of TRPV1 ion channels. Cell Calcium 35: 471-478, 2004.

MANDADI S, TOMINAGA T, NUMAZAKI M, MURAYAMA N, SAITO N, ARMATI PJ, ROUFOGALIS BD, TOMINAGA M: Increased sensitivity of desensitized TRPV1 by PMA occurs through PKCE-mediated phosphorylation at S800. Pain 123: 106-116, 2006.

MARSHALL IC, OWEN DE, CRIPPS TV, DAVIS JB, MCNULTY S, SMART D: Activation of vanilloid receptor 1 by resiniferatoxin mobilizes calcium from inositol 1,4,5-trisphosphate-sensitive stores. Br J Pharmacol 138: 172-176, 2003.

MASON L, MOORE RA, DERRY S, EDWARDS JE, MCQUAY HJ: Systematic review of topical capsaicin for the treatment of chronic pain. BMJ 328: 991, 2004.

MCMAHON SB, LEWIN G, BLOOM SR: The consequences of long-term topical capsaicin application in the rat. Pain 44: 301-310, 1991.

MCNAMARA FN, RANDALL A, GUNTHORPE MJ: Effects of piperine, the pungent component of black pepper, at the human vanilloid receptor (TRPV1). Br J Pharmacol 144: 781-790, 2005.

MOHAPATRA DP, NAU C: Desensitization of capsaicin-activated currents in the vanilloid receptor TRPV1 is decreased by the cyclic AMP-dependent protein kinase pathway. J Biol Chem 278: 50080-50090, 2003.

MOHAPATRA DP, NAU C: Regulation of $\mathrm{Ca}^{2+}$-dependent desensitization in the vanilloid receptor TRPV1 by calcineurin and cAMP-dependent protein kinase. J Biol Chem 280: 13424-13432, 2005.

MOHAPATRA DP, WANG SY, WANG GK, NAU C: A tyrosine residue in TM6 of the vanilloid receptor TRPV1 involved in desensitization and calcium permeability of capsaicin-activated currents. Mol Cell Neurosci 23: 314-324, 2003.

NAGY I, SANTHA P, JANCSO G, URBAN L: The role of the vanilloid (capsaicin) receptor (TRPV1) in physiology and pathology. Eur J Pharmacol 500: 351-369, 2004.

NILIUS B, OWSIANIK G, VOETS T, PETERS JA: Transient receptor potential cation channels in disease. Physiol Rev 87: 165-217, 2007.

NOLANO M, SIMONE DA, WENDELSCHAFER-CRABB G, JOHNSON T, HAZEN E, KENNEDY WR: Topical capsaicin in humans: parallel loss of epidermal nerve fibers and pain sensation. Pain 81: 135-145, 1999.

NOVAKOVA-TOUSOVA K, VYKLICKY L, SUSANKOVA K, BENEDIKT J, SAMAD A, TEISINGER J, VLACHOVA V: Functional changes in the vanilloid receptor subtype 1 channel during and after acute desensitization. Neuroscience 149: 144-154, 2007.

NUMAZAKI M, TOMINAGA T, TAKEUCHI K, MURAYAMA N, TOYOOKA H, TOMINAGA M: Structural determinant of TRPV1 desensitization interacts with calmodulin. Proc Natl Acad Sci USA 100: 8002-8006, 2003. 
NUMAZAKI M, TOMINAGA T, TOYOOKA H, TOMINAGA M: Direct phosphorylation of capsaicin receptor VR1 by protein kinase Cepsilon and identification of two target serine residues. J Biol Chem 277: 13375-13378., 2002.

OLAH Z, SZABO T, KARAI L, HOUGH C, FIELDS RD, CAUDLE RM, BLUMBERG PM, IADAROLA MJ: Ligand-induced dynamic membrane changes and cell deletion conferred by vanilloid receptor 1 . J Biol Chem 276: 11021-11030, 2001.

OWSIANIK G, D'HOEDT D, VOETS T, NILIUS B: Structure-function relationship of the TRP channel superfamily. Rev Physiol Biochem Pharmacol 156: 61-90, 2006.

PINGLE SC, MATTA JA, AHERN GP: Capsaicin receptor: TRPV1 a promiscuous TRP channel. Handb Exp Pharmacol 179: 155-171, 2007.

PIPER AS, YEATS JC, BEVAN S, DOCHERTY RJ: A study of the voltage dependence of capsaicin-activated membrane currents in rat sensory neurones before and after acute desensitization. $J$ Physiol Lond 518: 721733, 1999.

PLANELLS-CASES R, GARCIA-SANZ N, MORENILLA-PALAO C, FERRER-MONTIEL A: Functional aspects and mechanisms of TRPV1 involvement in neurogenic inflammation that leads to thermal hyperalgesia. Pflugers Arch 451: 151-159, 2005.

PREMKUMAR LS, AHERN GP: Induction of vanilloid receptor channel activity by protein kinase C. Nature 408: $985-$ 990, 2000.

ROSENBAUM T, GORDON-SHAAG A, MUNARI M, GORDON SE: $\mathrm{Ca}^{2+} /$ calmodulin modulates TRPV1 activation by capsaicin. J Gen Physiol 123: 53-62, 2004.

ROSENBAUM T, GORDON SE: Dissecting intersubunit contacts in cyclic nucleotide-gated ion channels. Neuron 33: 703-713, 2002.

SAWYNOK J: Topical and peripherally acting analgesics. Pharmacol Rev 55: 1-20, 2003.

SIMONE DA, NOLANO M, JOHNSON T, WENDELSCHAFER-CRABB G, KENNEDY WR: Intradermal injection of capsaicin in humans produces degeneration and subsequent reinnervation of epidermal nerve fibers: correlation with sensory function. $J$ Neurosci 18: 8947-8959, 1998.

SZALLASI A, BLUMBERG PM: Vanilloid (capsaicin) receptors and mechanisms. Pharmacol Rev 51: 159-212, 1999.

SZOLCSANYI J: Forty years in capsaicin research for sensory pharmacology and physiology. Neuropeptides 38: $377-$ 384, 2004.

TENDER GC, WALBRIDGE S, OLAH Z, KARAI L, IADAROLA M, OLDFIELD EH, LONSER RR: Selective ablation of nociceptive neurons for elimination of hyperalgesia and neurogenic inflammation. J Neurosurg 102: 522-525, 2005.

TOMINAGA M, CATERINA MJ, MALMBERG AB, ROSEN TA, GILBERT H, SKINNER K, RAUMANN BE, BASBAUM AI, JULIUS D: The cloned capsaicin receptor integrates multiple pain-producing stimuli. Neuron 21: 531-543, 1998.

TOMINAGA M, TOMINAGA T: Structure and function of TRPV1. Pflugers Arch 451: 143-150, 2005.

TURNER H, FLEIG A, STOKES A, KINET JP, PENNER R: Discrimination of intracellular calcium store subcompartments using TRPV1 (transient receptor potential channel, vanilloid subfamily member 1) release channel activity. Biochem J 371: 341-350, 2003.

VELLANI V, MAPPLEBECK S, MORIONDO A, DAVIS JB, MCNAUGHTON PA: Protein kinase C activation potentiates gating of the vanilloid receptor VR1 by capsaicin, protons, heat and anandamide. $J$ Physiol Lond 534: 813-825, 2001.

VENKATACHALAM K, MONTELL C: TRP channels. Annu Rev Biochem 76: 387-417, 2007.

VLACHOVÁ V, LYFENKO A, ORKAND RK, VYKLICKÝ L: The effects of capsaicin and acidity on currents generated by noxious heat in cultured neonatal rat DRG neurones. J Physiol Lond 533: 717-728, 2001.

VLACHOVÁ V, TEISINGER J, SUŠÁNKOVÁ K, LYFENKO A, ETTRICH R, VYKLICKÝ L: Functional role of Cterminal cytoplasmic tail of rat vanilloid receptor 1. J Neurosci 23: 1340-1350, 2003.

VOETS T, DROOGMANS G, WISSENBACH U, JANSSENS A, FLOCKERZI V, NILIUS B: The principle of temperature-dependent gating in cold- and heat-sensitive TRP channels. Nature 430: 748-754, 2004. 
WISNOSKEY BJ, SINKINS WG, SCHILLING WP: Activation of vanilloid receptor type I in the endoplasmic reticulum fails to activate store-operated $\mathrm{Ca}^{2+}$ entry. Biochem J 372: 517-528, 2003.

XU H, BLAIR NT, CLAPHAM DE: Camphor activates and strongly desensitizes the transient receptor potential vanilloid subtype 1 channel in a vanilloid-independent mechanism. J Neurosci 25: 8924-8937, 2005. 